B.G. Liubarskyi, L.V. Overianova, Ie.S. Riabov, D.I. Iakunin, O.O. Ostroverkh, Y.V. Voronin

\title{
ESTIMATION OF THE MAIN DIMENSIONS OF THE TRACTION PERMANENT MAGNET-ASSISTED SYNCHRONOUS RELUCTANCE MOTOR
}

\begin{abstract}
Goal. The goal of the research is to develop an algorithm for selecting the main dimensions of a traction permanent magnet-assisted synchronous reluctance motor. Methodology. A method for determining the main dimensions of the motor, which combines the analytical selection of stator parameters and numerical field calculations for the selection of rotor parameters. The need to check the mechanical strength of a rotor with permanent NdFeB magnets in flux barriers is shown. Results. The article proposes an algorithm for selecting the main dimensions of a traction permanent magnet-assisted synchronous reluctance motor, which combines analytical expressions for selecting stator parameters and numerical field calculations for selecting rotor parameters. It is determined that analytical methods for calculating the magnetic circuit need to be developed in order to reduce the time to select the main dimensions of the motor. Originality. For the first time the sizes of active parts of the permanent magnet-assisted synchronous reluctance motor with power of $180 \mathrm{~kW}$ for the drive of wheels of the trolleybus are defined. Practical significance. As a result of research the sizes of active parts, stator winding data and a design of a rotor of the electric motor are defined. The obtained results can be applied when creating an electric motor for a trolleybus. References 17, tables 3, figures 5.
\end{abstract}

Key words: permanent magnet-assisted synchronous reluctance motor, traction electric drive, permanent magnet, energy efficiency.

У статті розглянуті питання проектування тягового синхронно-реактивного електродвигуна з постійними магнітами потужністю 180 кВт для приводу коліс тролейбуса. Запропоновано спосіб визначення головних розмірів електродвигуна, який поєднує аналітичний вибір параметрів статора та чисельно-польові розрахунки для вибору параметрів ротора. Показана необхідність перевірки механічної міцності ротора, в якому розташовано постійні магніти NdFев у потокових бар'єрах. У результаті дослідження визначено розміри активних частин, обмоткові дані статора та конструктив ротора електродвигуна. Бібл. 17 , табл. 3 , рис. 5.

Ключові слова: синхронно-реактивний двигун 3 постійними магнітами, тяговий електропривод, постійний магніт, енергоефективність.

В статье рассмотрены вопросы проектирования тягового синхронно-реактивного электродвигателя с постоянными магнитами мощчностью 180 кВт для привода колес троллейбуса. Предложен способ определения главньх размеров электродвигателя, который сочетает аналитический выбор параметров статора и численно-полевые расчеты для выбора параметров ротора. Показана необходимость проверки механической прочности ротора, в котором расположено постоянные магниты NdFеB в потоковых барьерах. В результате исследования определены размерь активньх частей, обмоточные данные статора и конструктив ротора электродвигателя. Библ. 17, табл. 3 , рис. 5.

Ключевые слова: синхронно-реактивный двигатель с постоянными магнитами, тяговый электропривод, постоянный магнит, энергоэффективность.

Introduction. At present, the worldwide practice is the use of traction electric drives with induction electric motors on the rolling stock of railways, industrial and urban transport [1-3]. In Ukraine, large-scale traction induction electric drives are used in the rolling stock of urban electric transport and main railways [4]. The main advantages of the traction induction electric drive are high energy and mass-size indicators, high level of reliability, simplicity of design, long service life [5]. However, the requirements for reducing energy and resource consumption of rolling stock pose a task to the scientific and technical community both to the further improvement of traction induction electric drives, and the development and research of other types of electric drives [6]. An alternative approach to increase the efficiency of the traction electric drive is the use of synchronous motors with excitation from permanent magnets [7], but the large mass of high-coercive permanent magnets significantly increases the cost of production of such electric motors.
Analysis of literature data and problem definition. A specific feature of the traction drive is a wide range of speed and torque control, and therefore, it is important to ensure high energy performance of the traction drive in different operating modes. According to various authors, such characteristics are provided by permanent magnet-assisted synchronous reluctance motors (PMSynRM, PMA-SynRel) [8-12]. The weight and size of the motor of this type are comparable to an induction motor, and therefore the traction drive based on a permanent magnet-assisted synchronous reluctance motor is a «direct alternative» to the traction induction electric drive.

PMSynRM is a synchronous reluctance motor (SynRM) with permanent magnets inside the rotor. The configuration of a typical PMSynRM is shown in Fig. 1 [8-10].

In this motor, as a rule, a distributed stator winding is used $[10,11]$. To increase the use of reactive torque, in 


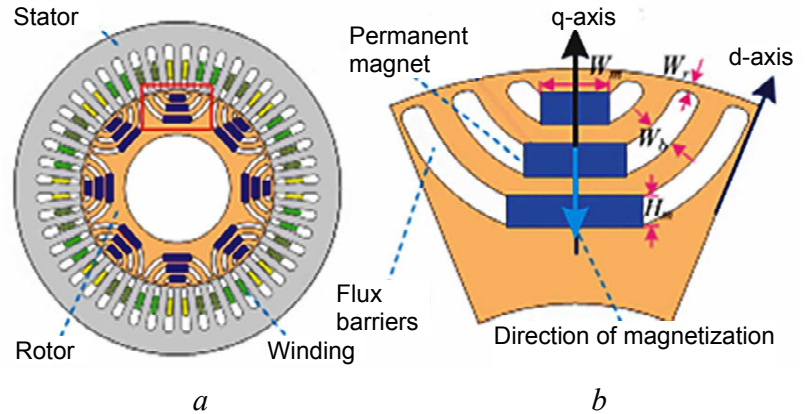

Fig. 1. PMSynRM configuration ( $a$ ) and rotor section (b). Marked: $W_{r}, W_{b}, W_{m}, H_{m}-$ tangential ribs, flux barriers, width and height of permanent rotor magnets, respectively

the radial direction of the rotor after another channels of flux barriers are placed one after another. A feature of the rotor is the presence of permanent magnets (rare earth magnets such as $\mathrm{NdFeB}$, ferrite $\mathrm{Y} 30$ ) inserted into its flux barriers [11-13]. The permanent magnets are uniformly magnetized and form the $q$-axis of the rotor. Because permanent magnets have about the same permeability as air, they create a path with high resistance and magnetic anisotropy in the $q$-axis direction. The steel part of the rotor is formed by small segments isolated from each other by flux barriers. These segments provide a path with low flux resistance along the $d$-axis. To ensure the strength of the rotor structure, it is necessary that the ferromagnetic segments are internally connected to each other, so the rotor structure uses tangential ribs near the air gap with thickness $W_{r}$ [14]. Due to the installation of permanent magnets, the tangential ribs are saturated during normal operation of the motor and therefore magnetically insulate various steel segments [14]. From the point of view of creating torque, the scattering of the flux caused by tangential ribs should be minimal [11].

A review of publications [10-14] shows that the determination of the dimensions and parameters of electric motors is carried out by numerical field calculations in combination with multicriteria optimization. The varied parameters are usually the geometric dimensions of the elements of the magnetic core. At the same time, since the PMSynRM stator is similar to the stator of an $\mathrm{AC}$ motor, it is obvious that the optimization model can be simplified by applying classical methods for calculating the magnetic circuit of electric machines for the stator, and using numerical calculations only to determine the motor's rotor configuration. In addition, this decomposition allows to estimate the size of the active parts of the motor and its fit into the allotted mounting space without numerical calculations of the magnetic field, resulting in a set of allowable geometric stator parameters.

The goal of the work is the development of an algorithm for selecting the main dimensions of a traction permanent magnet-assisted synchronous reluctance motor.
The aim of the study is the adaptation of methods for selecting the main sizes of electric machines for their application to PMSynRM.

A technique for choosing the main dimensions of PMSynRM. The main dimensions of an electric machine are the diameter of the armature or the diameter of the stator bore and their axial length. These dimensions depend on the power, rotation speed and a number of indicators that characterize the use of active parts of electric machines [5]. Features of traction electric machines are, firstly, the regulation of rotation speed in a wide range (the ratio of maximum rotation speed to nominal one can be from 3 to 5 times, and the ratio of maximum torque to nominal one - up to 2 times), and, secondly, restrictions of overall dimensions associated with the placement of the electric machine on the vehicle and its arrangement in the transmission. This in most cases makes it impossible to use the Arnold constant to determine the main dimensions of traction electric machines, so there are special procedures developed for them $[3,5]$. With this in mind, it is advisable to use this approach to select the main sizes of PMSynRM.

The number of pole pairs is determined from the condition of ensuring the maximum rotation speed at the highest frequency of the supply voltage:

$$
p=\frac{60 f_{\max }}{n_{\max }},
$$

where $f_{\max }$ is the highest supply frequency; $n_{\max }$ is the highest rotation speed.

Since the traction motor must have a high degree of protection, which is adopted in order to prevent dirt from entering the air gap between the stator and the rotor, cooling of the electric motor is possible only through the axial ventilation ducts in the stator. In the caseless design, the axial channels are made directly in the stator sheet, for example, by stamping. In the case of the stator housing, the axial ventilation channels of the stator are formed by the motor housing, to which the ribs for laminating the stator core are welded, and the outer surface of the stator core. Regardless of the method of formation of axial ventilation ducts, their radial size (diameter or height) can be taken equal to $12-20 \mathrm{~mm}$ (smaller values- in the case of the housing). Adding to this size the thickness of the housing of $8-10 \mathrm{~mm}$ and technological reserves for the manufacture of holes, we obtain the outer diameter of the stator magnetic core (calculated diameter of the active part). This value is subject to specification based on the results of calculations and design processing of the electric motor.

The inner diameter of the stator $D_{i}$ (diameter of the «bore») is determined by the expression

$$
D_{i}=K \cdot D_{a},
$$

where $K$ is the coefficient equal to, for example, $0.55-0.65$ at $2 p=4, p$ is the number of pole pairs, $D_{a}$ is the calculated diameter. 
To estimate the length of the stator magnetic core, calculate the departure of the front parts of the stator winding by expression

$$
L_{v}=(0,12+0,15 p) \cdot \tau_{k}+10,
$$

where $\tau_{k}$ is the average width of the stator coil.

Approximately the average width of the stator coil can be determined by expression

$$
\tau_{k}=\beta \frac{Z}{2 p} t_{a v 1}
$$

where $\beta$ is the reduction of the winding step (approximately assumed to be equal to 0,8 ); $Z$ is the number of slots in the stator; $t_{a v 1}$ is the toothed step in the middle of the height of the slot.

The largest number of slots is determined from the expression

$$
Z=\frac{(0,3 \ldots 0,4) \pi D_{i}}{b_{z}},
$$

where $b_{z}$ is the width of the stator tooth, which must be at least $5-7 \mathrm{~mm}$;

$$
t_{a v 1}=\frac{\pi\left(D_{i}+h_{n}\right)}{Z},
$$

where $h_{n}$ is the height of the slot which is determined by the expression

$$
h_{n}=(3 \ldots 4) b_{n},
$$

where $b_{n}$ is the width of the slot which is equal to

$$
b_{n}=t_{z 1}-b_{z} \text {, }
$$

where $t_{z 1}$ is toothed step on the inner diameter of the stator

$$
t_{z 1}=\frac{\pi D_{i}}{Z}
$$

The size of the axial length of the stator on the front parts

$$
L_{l}=(0,7 \ldots 0,8) L_{k},
$$

where $L_{k}$ is the body length (distance between the planes of bearing plates).

The axial length of the stator magnetic core is determined by the expression

$$
L_{i}=L_{l}-L_{v} .
$$

The phase current of the motor is predetermined by the expression

$$
I_{p h}=\frac{P \cdot 10^{3}}{3 \cdot U_{p h} \cdot \eta \cdot \cos \varphi},
$$

where $P$ is the nominal power; $U_{p h}$ is the nominal phase voltage; $\eta$ is efficiency (approximately 0.93-0.95); $\cos \varphi$ is the power factor (approximately 0.8-0.9).

The magnetic flux of the motor is pre-determined by the expression

$$
\Phi=\alpha B_{\delta} \tau L_{i},
$$

where $\alpha$ is the coefficient of the pole arc (take equal to $2 / \pi) ; B_{\delta}$ is the magnetic flux density in the air gap (take no more than $1 \mathrm{~T}$ ); $\tau$ is the pole division.

The pole division is determined by the expression

$$
\tau=\frac{\pi D_{i}}{2 p}
$$

The number of turns in the phase of the stator winding is determined by the expression

$$
w=\frac{(0,95 \ldots 0,98) U_{p h}}{4,44 \Phi f_{n o m} k_{w 1}},
$$

where $U_{p h}$ is the phase voltage; $k_{w 1}$ is the winding coefficient (take equal to 0,9 ); $f_{\text {nom }}$ is the nominal voltage frequency

$$
f_{\text {nom }}=\frac{p n_{\text {nom }}}{60},
$$

where $n_{\text {nom }}$ is the nominal rotation speed of the motor.

The number of effective conductors in the slot

$$
s_{n}=\frac{2 m a w}{Z},
$$

where $m$ is the number of phases of the motor (equal to 3 ); $a$ is the number of parallel branches (the current of the parallel branch should not exceed $400 \mathrm{~A}$ ).

It is advisable to choose the number of parallel branches from the condition of providing a whole number of slots per pole and phase

$$
q=\frac{Z}{2 p m a} .
$$

Preliminary assessment of the rotor configuration (number of flux barriers, geometric dimensions of permanent magnets) is performed by calculating the magnetic circuit of the motor using substitution circuits. The criterion for selecting a configuration option is to provide nominal torque at nominal phase current. The values of magnetic flux density in the parts of the magnetic core are analyzed and, if necessary, its geometric dimensions are adjusted.

When calculating the parameters of permanent magnets are taken according to the data given in Table 1 .

Table 1

Parameters of permanent magnets

\begin{tabular}{|l|c|c|}
\hline \multicolumn{1}{|c|}{ Name } & Unit & Value \\
\hline Material of magnets & & $\mathrm{NdFeB}$ \\
\hline Remanent flux density & $\mathrm{T}$ & 1,0 \\
\hline Coercive force & $\mathrm{kA} / \mathrm{m}$ & 850 \\
\hline
\end{tabular}

The next step is to calculate the magnetic field of the motor in the FEMM environment, which clarifies the results of the previous calculation [15-17].

Auxiliary criteria when choosing the configuration of the rotor are to ensure its mechanical strength, as well as satisfactory results of thermal calculation of the electric motor.

As an example, consider the procedure for selecting the main dimensions of PMSynRM to drive the wheels of a trolleybus with the technical parameters listed in Table 2. Technical parameters correspond to traction induction electric motors used in trolleybuses. 
Table 2

Technical parameters of PMSynRM

\begin{tabular}{|l|c|c|}
\hline \multicolumn{1}{|c|}{ Name } & Unit & Value \\
\hline Power & $\mathrm{kW}$ & 180 \\
\hline Linear voltage & $\mathrm{V}$ & 400 \\
\hline Phase current & $\mathrm{A}$ & 350 \\
\hline Nominal rotation speed & $\mathrm{Rpm}$ & 1500 \\
\hline Torque & $\mathrm{Nm}$ & 1110 \\
\hline Maximum rotation speed & $\mathrm{Rpm}$ & 4000 \\
\hline Maximum supply frequency & $\mathrm{Hz}$ & 150 \\
\hline
\end{tabular}

The selection criterion is to ensure the torque $1100 \mathrm{Nm}$ at phase current of $350 \mathrm{~A}$. From the analysis of designs of similar induction motors (AD903, DTA-1, 6DTA.002.1) we find that the external diameter of the electric motor should not exceed $500 \mathrm{~mm}$, axial length on the case $-700 \mathrm{~mm}$.

The procedure for determining the main dimensions of the traction PMSynRM is a series of calculations, which consist of calculations by analytical expressions (1) - (17), magnetic field calculations in FEMM environment (Fig. 2) and rotor strength calculations (Fig. 3). The calculations were performed for several values of the number of stator slots, after which the number of effective conductors in the slot was determined. After that, the calculations of the magnetic circuit of the stator were performed to assess the magnetic flux density in the teeth and the yoke (permissible values - not more than 1.7 T. In case of excess -the geometric dimensions of the slots were adjusted). Next, a sketch of the cross section of the motor was developed to calculate the magnetic field in the FEMM environment. Calculations were performed for rotor configuration options with two and three pairs of flux barriers. The thickness of the flux barrier was assumed to be $10 \mathrm{~mm}$. The distance between the flux barriers in one layer is 5 mm. All flux barriers contain permanent magnets with parameters according to Table 1 . The calculation of the magnetic field of the electric motor is performed for the stator current $350 \mathrm{~A}$, according to which, taking into account the scheme of the stator winding, the magnetomotive force of the conductors of the stator winding is calculated. Calculations are performed for several positions of the rotor. For calculation options where the electromagnetic torque reaches more than $1100 \mathrm{Nm}$, calculations of a rotor on strength at frequency of rotation of $4800 \mathrm{rpm}$ are carried out. If the mechanical strength of the rotor is provided (it is assumed that the safety factor should be greater than 2), the option is accepted as working.

After performing the above series of calculations, the configuration of PMSynRM was determined which satisfies the technical parameters specified in Table 2.

The stator data are given in Table 3 , the results of the calculation of the magnetic field - in Fig. 2, the results of the calculation of the rotor on strength - in Fig. 3. The sketch of the rotor is shown in Fig 4, the dependence of the torque of the motor on the angle of rotation of the rotor - in Fig. 5.

Table 3

Stator data

\begin{tabular}{|l|c|}
\hline \multicolumn{1}{|c|}{ Name } & Value \\
\hline Number of slots & 36 \\
\hline Number of effective conductors in the slot & 6 \\
\hline Number of parallel branches & 1 \\
\hline Step reduction ratio & 0,778 \\
\hline $\begin{array}{l}\text { Number of elementary conductors in the } \\
\text { effective one }\end{array}$ & 3 (in height) \\
\hline Step on the slots & $1-8-19$ \\
\hline \multicolumn{2}{|c|}{} \\
\hline Calculated outer diameter of the stator, $\mathrm{m}$ & 0,46 \\
\hline Boring diameter, $\mathrm{m}$ & 0,3 \\
\hline Axial length of the magnetic core, $\mathrm{m}$ & 0,3 \\
\hline One-side air gap, m & 0,001 \\
\hline $\begin{array}{l}\text { Dimensions of the stator winding conductor } \\
\text { (without insulation), mm }\end{array}$ & $1,6 \times 12,5$ \\
\hline Slot height, m & 0,040 \\
\hline Slot width, m & 0,0145 \\
\hline
\end{tabular}

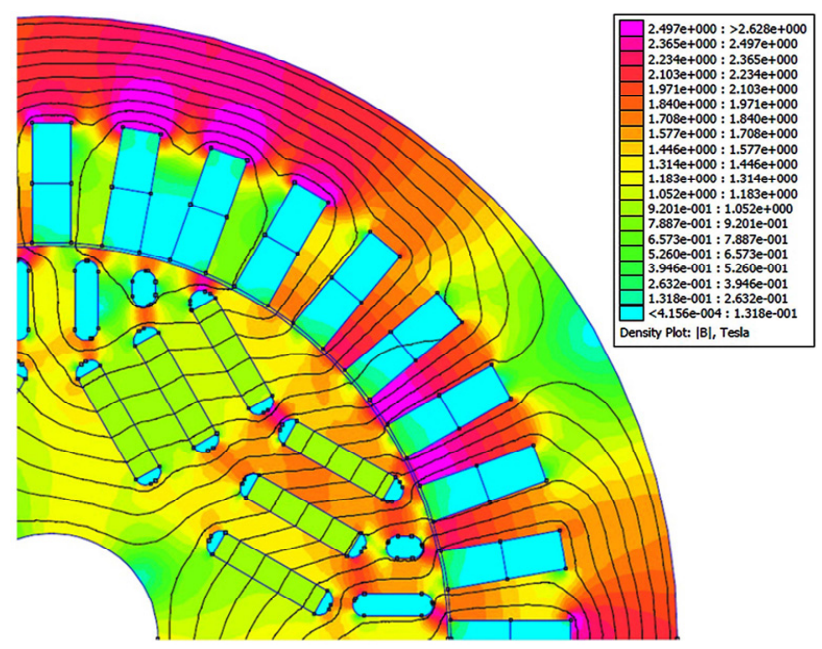

Fig. 2. Results of the calculation of the magnetic field in FEMM

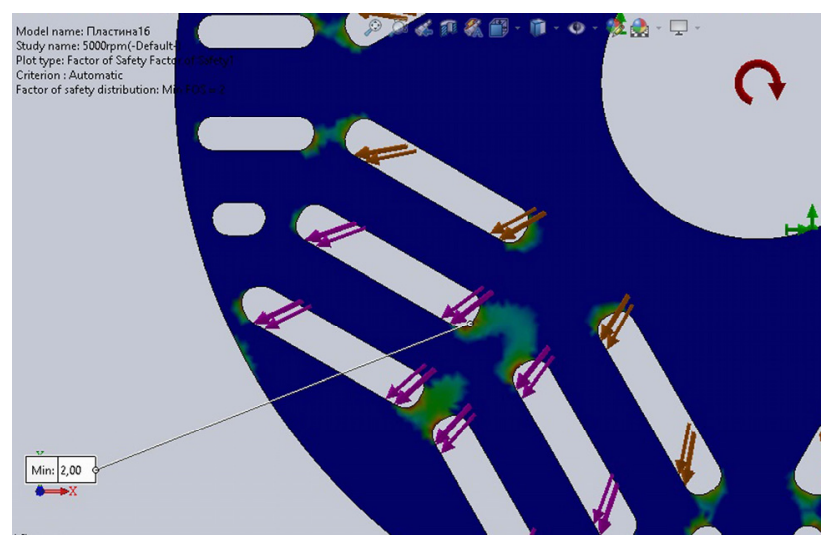

Fig. 3. Results of the calculation of the rotor on strength in SolidWorks Simulation 


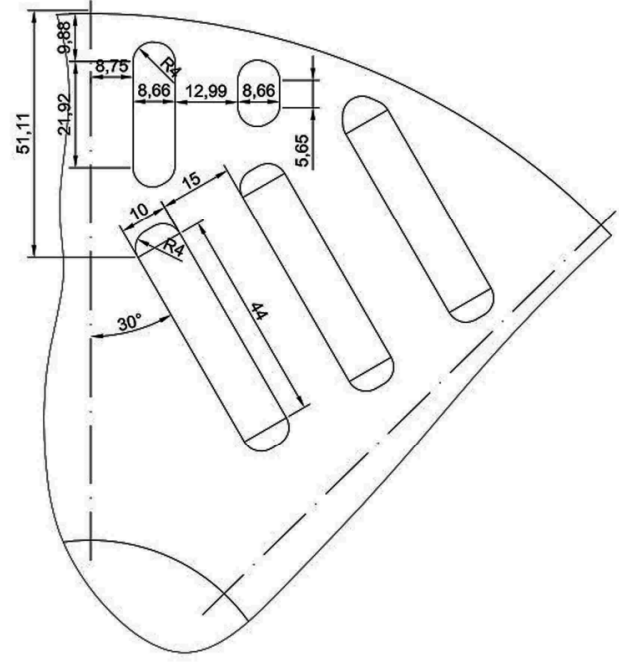

Fig. 4. Sketch of the PMSynRM rotor

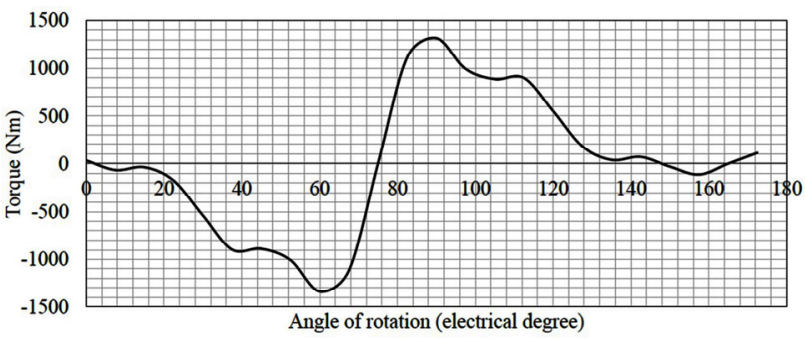

Fig. 5. Dependence of the torque on the angle of rotation of the rotor

As it can be seen from Fig. 5, the required torque equal to $1100 \mathrm{Nm}$ is achieved by the calculated configuration of the active parts of the motor. However, it should be noted that in the given example of the PMSynRM configuration, the maximum torque of the electric motor does not significantly exceed the nominal torque, which can negatively affect the performance of the traction drive of the trolleybus.

Discussion of results. The proposed technique allowed to determine the parameters of the PMSynRM stator analytically, which reduced the number of options for numerical field calculations. The technique was tested in the calculation of PMSynRM with power of $180 \mathrm{~kW}$ for the drive of trolleybus wheels. In order to further reduce the numerical field calculations, it is advisable to analytically determine the parameters for assessing the performance of the electric motor. It is necessary to define and apply in the developed methodology criteria that take into account the frequency control of the motor.

\section{Conclusions.}

1. The paper proposes an algorithm for selecting the main dimensions of a traction permanent magnet-assisted synchronous reluctance motor which combines analytical expressions for selecting stator parameters and numerical field calculations for selecting rotor parameters. The technique was tested in determining the configuration of PMSynRM with power of $180 \mathrm{~kW}$.

2. It is determined that analytical methods for calculating the magnetic circuit need to be developed in order to reduce the time for choosing the main dimensions of the electric motor.

3. Techniques of heat-ventilation calculations of a traction permanent magnet-assisted synchronous reluctance electric motor and methods of calculation of its characteristics, based on the results of which a decision is made on the conformity of the electric motor to technical requirements, need to be developed.

Conflict of interest. The authors declare no conflict of interest.

\section{REFERENCES}

1. Luvishis A.L. Asynchronous drive: the beginning of the path. Lokomotiv, 2017, no. 1 (721), pp .44-46. (Rus).

2. Luvishis A.L. New locomotives of the US railways. Railway transport, 2018, no. 8, pp. 70-77. (Rus).

3. Lyubarsky B.G. Teoretychni osnovy dlia vyboru ta otsinky perspektyvnykh system elektromekhanichnoho peretvorennia enerhii elektrorukhomoho skladu: dys. dokt. tekhn. nauk [Theoretical bases for a choice and an estimation of perspective systems of electromechanical conversion of energy of an electric rolling stock: Dr. tech. sci. dissertation]. Kharkiv, NTU «KhPI», 2014. 368 p. (Ukr).

4. Yatsko S., Sytnik B., Vashchenko Y., Sidorenko A., Liubarskyi B., Veretennikov I., Glebova M. Comprehensive approach to modeling dynamic processes in the system of underground rail electric traction. Eastern-European Journal of Enterprise Technologies, Jan. 2019, vol. 1, no. 9 (97), pp. 48-57. doi: https://doi.org/10.15587/1729-4061.2019.154520.

5. Bezruchenko V.M., Varchenko V.K., Chumak V.V. Tiahovi elektrychni mashyny elektrorukhomoho skladu [Traction electric machines of electro-rolling stock]. Dnipropetrovsk, DNUZT Publ., 2003. 252 p. (Ukr).

6. Yatsko S., Sidorenko A., Vashchenko Ya., Lyubarskyi B., Yeritsyan B. Method to improve the efficiency of the traction rolling stock with onboard energy storage. International journal of renewable energy research, 2019, vol. 9, no. 2, pp. 848-858. Available https://www.ijrer.org/ijrer/index.php/ijrer/article/view/9143/pdf (Accessed 15.08.2020).

7. Liubarskyi B., Demydov A., Yeritsyan B., Nuriiev R., Iakunin D. Determining electrical losses of the traction drive of electric train based on a synchronous motor with excitation from permanent magnets. Eastern-European Journal of Enterprise Technologies, Apr. 2018, vol. 2, no. 9 (92), pp. 29-39. doi: https://doi.org/10.15587/1729-4061.2018.127936.

8. Stipetic S., Zarko D., Kovacic M. Optimised design of permanent magnet assisted synchronous reluctance motor series using combined analytical-finite element analysis based approach. IET Electric Power Applications, May 2016, vol. 10, no. 5, pp. 330-338. doi: https://doi.org/10.1049/ietepa.2015.0245.

9. Haataja J., Pyrhönen J. Permanent magnet assisted synchronous reluctance motor: an alternative motor in variable speed drives. In: Parasiliti F., Bertoldi P. (eds) Energy Efficiency in Motor Driven Systems, 2003. Springer, Berlin, Heidelberg. doi: https://doi.org/10.1007/978-3-642-55475-9 16.

10. Krause P.C., Wasynczuk O., Pekarek S.D. Electromechanical Motion Devices. 2nd ed. 2012, Wiley-IEEE, $544 \mathrm{p}$.

11. Viego-Felipe P.R., Gómez-Sarduy J.R., Sousa-Santos V., Quispe-Oqueña E.C. Motores sincrónicos de reluctancia 
asistidos por iman permanente: Un nuevo avance en el desarrollo de los motores eléctricos. Ingeniería, investigación y tecnología, Jul. 2018, vol. 19, no. 3, pp. 269-279. doi: https://doi.org/10.22201/fi.25940732e.2018.19n3.023. (Esp).

12. Wu W., Zhu X., Quan L., Du Y., Xiang Z., Zhu X. design and analysis of a hybrid permanent magnet assisted synchronous reluctance motor considering magnetic saliency and PM usage. IEEE Transactions on Applied Superconductivity, April 2018, vol. 28, no. 3, pp. 1-6, art no. 5200306. doi: https://doi.org/10.1109/tasc.2017.2775584.

13. Reza R. Moghaddam. Synchronous Reluctance Machine (SynRM) in Variable Speed Drives (VSD) Applications Theoretical and Experimental Reevaluation. Doctoral Thesis. Royal Institute of Technology, Stockholm, Sweden, 2011, 260 p. Available at : http://www.divaportal.org/smash/get/diva2:417890/FULLTEXT01.pdf

(Accessed 21.09.2020).

14. Dehghani Ashkezari J., Khajeroshanaee H., Niasati M., Jafar Mojibian M. Optimum design and operation analysis of permanent magnet-assisted synchronous reluctance motor. Turkish journal of electrical engineering \& computer sciences, 2017, vol. 25, pp. 1894-1907. doi: https://doi.org/10.3906/elk1603-170.

15. Juergens J., Fricassè A., Marengo L., Gragger J., De Gennaro M., Ponick B. Innovative design of an air cooled ferrite permanent magnet assisted synchronous reluctance machine for automotive traction application. 2016 XXII International Conference on Electrical Machines (ICEM), Lausanne, Switzerland, 2016, pp. 803-810. doi: https://doi.org/10.1109/icelmach.2016.7732618.

16. Trancho E., Ibarra E., Arias A., Kortabarria I., Jurgens J., Marengo L., Fricasse A., Gragger J.V. PM-Assisted
Synchronous Reluctance Machine Flux Weakening Control for EV and HEV Applications. IEEE Transactions on Industrial Electronics, April 2018, vol. 65, no. 4, pp. 2986-2995. doi: https://doi.org/10.1109/tie.2017.2748047.

17. Finite Element Method Magnetics. Available at: https://www.femm.info/wiki/HomePage (accessed 15.06.2020).

Received 22.12.2020

Accepted 07.02.2021

Published 05.04.2021

B.G. Liubarskyi ${ }^{1}$, Doctor of Technical Science, Professor,

L.V. Overianova ${ }^{1}, P h D$, Associate Professor,

Ie.S. Riabov ${ }^{1}$, PhD, Senior Researcher,

D.I. Iakunin ${ }^{1}, P h D$, Associate Professor,

O.O. Ostroverk ${ }^{1}, P h D$,

Y.V. Voronin ${ }^{2}$,

${ }^{1}$ National Technical University «Kharkiv Polytechnic Institute», 2, Kyrpychova Str., Kharkiv, 61002, Ukraine, e-mail: lboris1911@ukr.net, overanova@ukr.net, riabov.ievgen@gmail.com, unicomber@ukr.net, ostrov.sasha@gmail.com

2 JSC «Electromashina», 106, Ozeryanskaya Str., Kharkiv, 61016, Ukraine, e-mail: designer.voronin@gmail.com

How to cite this article:

Liubarskyi B.G., Overianova L.V., Riabov Ie.S., Iakunin D.I., Ostroverkh O.O., Voronin Y.V. Estimation of the main dimensions of the traction permanent magnet-assisted synchronous reluctance motor. Electrical Engineering \& Electromechanics, 2021, no. 2, pp. 3-8. doi: 10.20998/2074-272X.2021.2.01. 